\title{
LUT
}

University

\section{Creating value with integrated B2B solutions: an empirical study of network maintenance services}

\author{
Pynnönen Mikko, Immonen Mika, Hallikas Jukka
}

This is a Author's accepted manuscript (AAM) version of a publication

published by Inderscience Enterprises Ltd.

in International Journal of Services and Operations Management

DOI: $10.1504 /$ IJSOM.2019.097531

Copyright of the original publication: (c) 2019 Inderscience Enterprises Ltd.

Please cite the publication as follows:

Pynnönen, M., Immonen, M., Hallikas, J. (2019). Creating value with integrated B2B solutions: an empirical study of network maintenance services. International Journal of Services and Operations Management, vol. 32, issue 2, pp. 249-267. DOI: 10.1504/IJSOM.2019.097531

This is a parallel published version of an original publication. This version can differ from the original published article. 


\title{
Creating value with integrated B2B solutions: an empirical study of network maintenance services
}

\author{
Mikko Pynnönen*, Mika Immonen ${ }^{\mathrm{a}}$ and Jukka Hallikas ${ }^{\mathrm{b}}$ \\ *Corresponding author \\ mikko.pynnonen@lut.fi \\ $+358505487026$ \\ ${ }^{a}$ mika.immonen@lut.fi \\ b jukka.hallikas@lut.fi \\ All authors are affiliated with: \\ School of Business and Management \\ Lappeenranta University of Technology \\ Skinnarilankatu 3453850 Lappeenranta, Finland
}

\begin{abstract}
The objective of this paper is to analyse the structure of a network maintenance service solution and the role of intertwined service functions in creating value for customers. It is proposed that inherent in a solution are service functions highly valued by customers and connected with other service functions. These functions, which are the value drivers of the solution, are referred to in this paper as systemic service functions. It is necessary to identify these service functions in a solution's design to optimise the value of the whole solution. This study presents an empirical case analysis in the field of network maintenance services to enhance the understanding of value creation logic regarding integrated solutions. Social Network Analysis (SNA) and statistical methods will be applied to analyse a survey sample of the network service provider's customer companies. The SNA approach serves to describe service function structure from a customer perspective. Regression analysis will be applied to connect the expected value of the service solutions to the expected quality attributes. The findings indicate that systemic service functions commonly relate to routine processes and are bound by a usage context in customer problem-solving domains. This research is expected to open up the structural role of systemic service functions in service solutions and supply chain
\end{abstract}


integration, as well as provide the means to analyse service design and value creation systematically in solutions.

Keywords: Value creation, integrated solutions, product-service system, social network analysis, network maintenance services.

\section{Biographical notes:}

Dr. Mikko Pynnönen is Associate Professor at Lappeenranta University of Technology (LUT). He holds a D.Sc. (Econ. \& Bus. Adm.) degree from LUT. Dr. Pynnönen is director in several research projects in the field of services and business development. His main research interests include value creation in business systems. He has published over 60 scientific articles on business models and value in, for example, the Journal of Business Strategy, International Journal of Production Economics and Journal of Purchasing and Supply Management. He has developed these topics in close connection with a number of firms from a wide variety of industries, including e.g. ICT, Healthcare, Forest and Energy.

Dr. Mika Immonen is post-doctoral researcher at School of Business and Management at Lappeenranta University of Technology (LUT), Finland. He holds a D.Sc. (Tech.) degree from Lappeenranta University of Technology. His main research interests include service innovation and value network management in the intersection of ICT, energy and the healthcare sector. He has worked in various researches focusing on health care technology and consumer behaviour in health related services. Via numerous research projects, he has accumulated experience also from field of utility service development and smart grid business. His accomplished academic 
works consider services systems structures, emerging business models and customer value creation in multi-stakeholder environments.

Jukka Hallikas is a Professor of Supply Chain Management at the Lappeenranta University of Technology (LUT), Finland. His research interests focuses on the purchasing and supply management, risk management in supply networks, and service management.

\section{Introduction}

At its most basic definition, a service business model relies on controlled interactions with customers and the building of offerings to create value for customers. These elements are operationalised through collaboration in a multi-stakeholder network of individual decision makers and organisations (Alexander, Walker, and Naim, 2014; Vargo and Lusch, 2004). In this new paradigm, practitioners and scholars must adopt frameworks to help identify the network structures that provide the best basis for robust business models, and non-hierarchical organisation is needed for the purposeful design and delivery of services (Jaaron and Backhouse, 2014; Ukko, J. and Pekkola, S., 2015; Wang, Lai, and Hsiao, 2015). In practice, the biggest questions involve expectations of flexibility in terms of shaping cross-firm activities according to the type of service model in focus (Saccani, Visintin, and Rapaccini, 2014; Thomé, Scavarda, Pires, Ceryno, and Klingebiel, 2014; Vivaldini and Pires, 2016).

The existence of complex product and service systems in which value creation involves both the firm and the customer has long been recognised in the literature (Zhang et al., 2016). However, the existing literature lacks a framework by which to describe the link between sustainable customer value creation and service network modelling in emergent or uncertain environments (Alexander et al., 2014; Segura and Maroto, 2017). The problem here is that 
changing the activity focus from product and service development to understanding customers' business processes has an unavoidable impact on firm competitiveness (Bettencourt et al., 2002). According to Levitt (1980), a product is a complex combination of both the tangible and the intangible satisfaction of customer value. As an entity, it consists of the generic product, which in turn consists of the actual component(s) of the product or service and three other layers (expected, augmented and potential). These layers expand the generic product by contributing different value-adding items such as delivery, support and information (Levitt, 1980; Ulrich, 1995). Recent discussions have turned towards integrated solutions (e.g. Brady et al., 2005), the aim in customer problem solving being to amalgamate products and services into an interconnected value-creating system (Park et al., 2012). The concept of an integrated solution is based on the principles of product bundling and modularity (Andrews et al., 2010; Shocker et al., 2004; Ulrich, 1995), meaning that complementary products are sold together, but it also goes further to include customer understanding and customisation.

Currently, the field lacks an understanding of the premises on which integrated solutions are built (Dass and Fox, 2011; De Rosa et al., 2013). While value to a customer of a single product or service is fairly simple to assess, analytical complexity increases with the number of intertwined products and services in the solution. Further, customer engagement with value cocreation depends on the type of service influencing the buyer-seller relationship (Zhang and Chen, 2008). This varies among linkages in business processes, legal bonds, relationshipspecific adaptations and norms between parties (Rintala, Karppinen, and Koivuniemi, 2016; Saccani et al., 2014). Regardless of the importance of relationship characteristics, most studies in this field have focused on the value (co-)creation process in the context of integrated solutions and have not examined structure and design aspects (e.g. Aarikka-Stenroos and Jaakkola, 2012; Davies et al., 2006; Davies et al., 2007; Epp and Price, 2011; Roehrich and Caldwell, 2012; Tuli et al., 2007; Windahl and Lakemond, 2006). In this way, the literature examining solution 
design goes inside the integrated solution (e.g. Chen and Liu, 2005; Dahmus et al., 2001; Geum et al., 2011; Lin et al., 2011; Persson and Ahlstrom, 2006; Ulrich, 1995) but does not connect the analysis to the larger context of customer problem solving and value creation. In the present study, it is expected that integrating supply chain management with customer analysis will provide a means to describe inter-organisational structures and the responsibilities of the individual companies within a business network (Halldórsson, Hsuan, and Kotzab, 2015).

This paper aims to understand the structure of a service solution and the role of intertwined service functions in creating customer value. The selected approach links value co-creation interaction modelling and service network modelling to provide new insight into business strategies in complex environments (Dragoicea et al, 2015). Infrastructure management services in which the use of integrated services have recently emerged will be used as a case study to demonstrate the framework. It is proposed that service functions that are highly valued by customers and simultaneously highly intertwined with other service functions are inherent in a solution. The value drivers of the solution, these functions will be referred to as 'systemic service functions'. The research question, therefore, is as follows: How do systemic service functions and their integration drive the customer value of solutions? To optimise the value of the whole solution, it is first necessary to identify these systemic service functions in the solution design. The main contribution of the current research is expected to be in that it will open the structural role of systemic elements in service solution and supply chain integration, thus providing the means to analyse solution service design and value creation systematically.

The present paper is organised as follows: Section 2 below presents a discussion of the creation of customer value at the conceptual and theoretical levels from a systemic perspective. Section 3 describes the methodology used and data obtained by the current study. Section 4 describes the results of the data collection and analysis used in the present study. Finally, section 5 
presents the conclusions drawn from the results, identifies the study's limitations and offers suggestions for further research.

\section{Theoretical background}

Integrated solutions are rooted in both engineering and design science (Park et al., 2012) and marketing literature (e.g. Aarikka-Stenroos and Jaakkola, 2012; Davies et al., 2006; Davies et al., 2007; Epp and Price, 2011; Tuli et al., 2007). An integrated solution is treated either as a 'black box' that concentrates analyses on value creation in customer processes, or as a modular product-service system that focuses on the internal structure of the integrated solution. The following sections draw from and synthesise the existing literature regarding value creation with integrated solutions. The conceptual framework for the current paper is illustrated in figure 1.

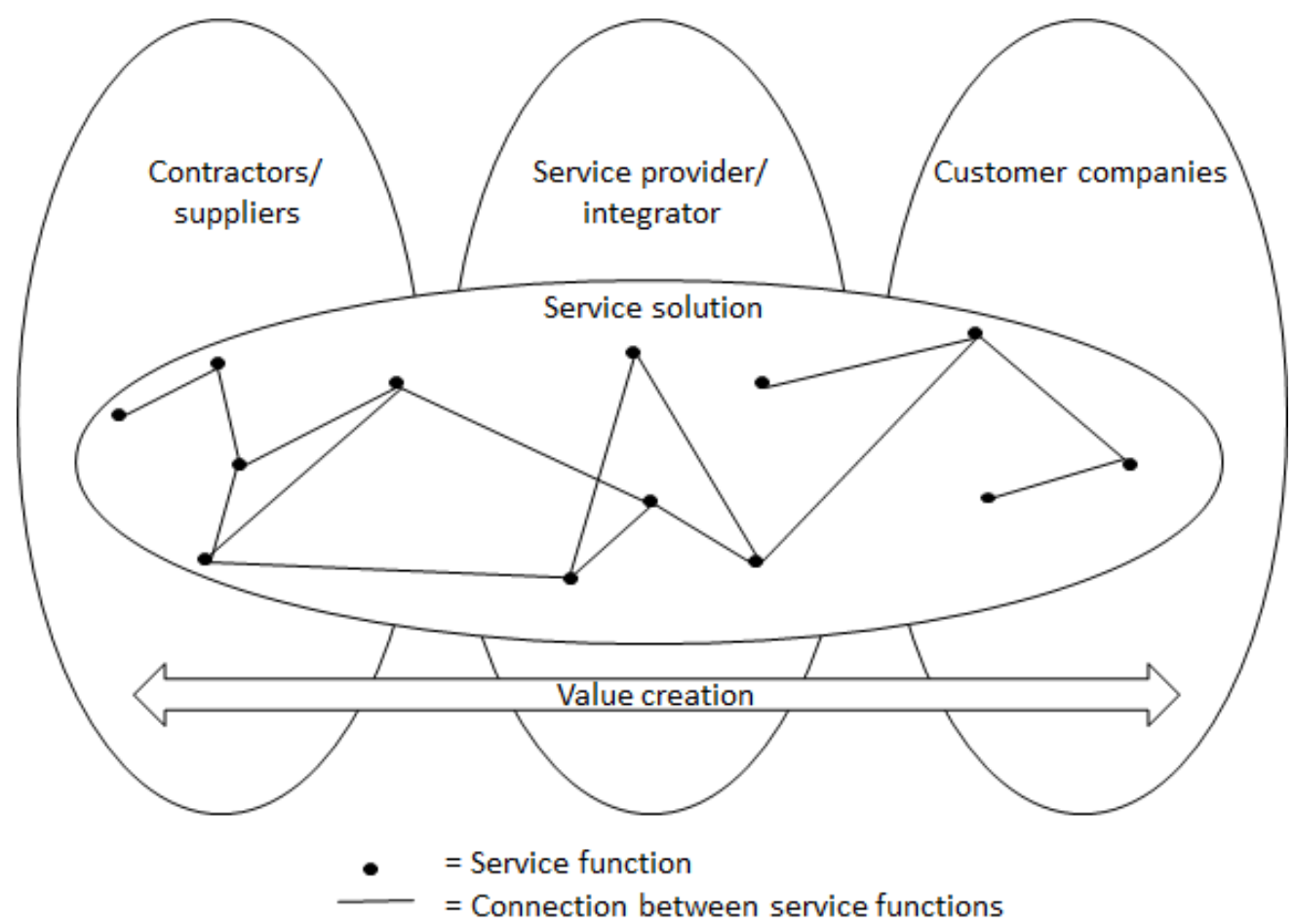

Figure 1. Conceptual framework of the study. 


\subsection{Value creation in services}

According to the literature on value creation, creating customer value is the essence of a firm's existence (e.g. Bowman and Ambrosini, 2000). This is even more pronounced in service contexts; it may well be the starting point for designing services and could determine a firm's competitiveness (e.g. Howden and Pressey, 2008; Hu et al., 2009; Vargo et al., 2008). Value co-creation integrates the customer into the service process and requires an understanding of all the activities that influence the service's perceived benefits (Larivière et al., 2013; Harmsen and Jensen, 2004; Thomke and von Hippel, 2002; Ulaga and Chacour, 2001; Ukko, J. and Pekkola, S., 2015). In this study, expectations of value prior to the acquisition of a certain service are examined, assuming the customers make rational decisions in relation to costs and sacrifices (McDougall and Levesque, 2000; Flint et al., 1997). Customer value in this sense refers to what the customer wants, given certain limitations such as time and financial resources, and is therefore a significant determinant of customer satisfaction. This satisfaction in turn influences the continuation (or discontinuation) of a given service (McDougall and Levesque, 2000). The value anticipated by the customer assumes three things: the rationality of the decisions, the subjectivity of the value assessment and the dynamics between attributes during the evaluation-use-repurchase process. Combined, the expected value is an anticipation of the value outcome following use of the service (Shankar et al., 2003). The value outcome in complex business service supply chains often comes down to the reliability and assurance of the service and service provider (e.g. Åhlström and Nordin, 2006; Hofenk et al., 2011; Hawkins et al., 2015).

\subsection{Services in an industrial context}

A service in the industrial context is a process for and in collaboration with another party through the integration of internal and external capabilities to co-create value (Grönroos and Voima, 2013; Ulaga and Chacour, 2001). This value creation process is often facilitated by 
integrating multiple service functions into a solution to a customer's problem. Solutions are defined in the literature as systems of physical products, services or knowledge designed to fulfil customer-specific needs (Epp and Price, 2011; Roehrich and Caldwell, 2012; Tuli et al., 2007; Windahl and Lakemond, 2006). The customer also has a major role in the creation of value in service solutions (e.g. Bettencourt et al., 2002; Grönroos and Ravald, 2011; Normann and Ramirez, 1993), specifically in defining the services required from the provider's portfolio. As such, the service provider must foster flexibility at the value network level and be able to create cross-firm strategies (Thomé et al., 2014; Vivaldini and Pires, 2016). The customer also contributes to value creation during the delivery process in offering information, rights and tangible products to the service provider (Fliess and Kleinaltenkamp, 2004). The existing discussion on this complex process (e.g. Englis and Solomon, 1996; Shocker et al., 2004) builds on the idea that value creation involves several interrelated and synergistic parts in addition to the tangible product, and that these parts all affect the customer's purchasing decisions. This phenomenon has been referred to in the recent literature as the systemic nature of customer value (Hallikas et al., 2014; Lusch et al., 2010; Pynnönen et al., 2011; Pynnönen et al., 2014), meaning that the value created with a customer depends on more than one part of the firm's product and service portfolio, more than one attribute of customer value and, potentially, more than one firm (Pynnönen et al., 2011).

\subsection{Service integration}

To delve deeper into the systemic nature of customer value, discussion of the phenomenon of complex services is required from the perspective of integration. Integrated solutions are defined as unique combinations of products and services that work together to increase the overall value of the solution for the customer (Brady et al., 2005). They are jointly built in an evolving relationship between the providing company and the customer (Tuli et al., 2007; Vargo et al., 2008). Targeted to match several categories of customer needs, the integrated 
solutions form a complex system of dynamic relationships embodied by operation, information, legal and co-operational linkages (Cannon and Perreault Jr., 1999; Karatzas, Johnson, and Bastl, 2016; Englis and Solomon, 1996; Ennen and Richter, 2010; Shocker et al., 2004). As Englis and Solomon (1996) argue, because complex service systems (they use the term 'consumption constellations') are grounded in product complementarity, they may serve as organising frameworks to link customers and service providers. A firm that understands its customers' goal structures and decision making may be able to design changeable solutions for different customer groups, even with different integration stages, and to adapt the service system into the evolving environment (Dragoicea et al., 2015).

A solution in this context can be mapped as a modular, interconnected system of functions to reveal the underlying structure and operating logic (Dahmus et al., 2001; Geum et al., 2011; Ulrich, 1995). The solution may include different functions that enable main classes of services, such as product support, customer support and process-related services (Saccani et al., 2014). In the mentioned service types, the key principle is the system's functional structure; the products and services are categorised into service functions that describe what they do, not what they are (Ulrich, 1995). One product or service may enable one or several service functions, and one service function, again, could be enabled via several products and services (Chen and Liu, 2005; Dahmus et al., 2001; Geum et al., 2011; Persson and Ahlstrom, 2006; Ulrich, 1995). According to this logic, value is not delivered via the product or service itself, but via the service function (Alonso-Rasgado et al., 2004).

Customers value these service functions differently depending on their needs (Pynnönen et al., 2014). The function-driven logic of a solution thus becomes a basis for competitiveness, as managing the core elements of the solution is necessary for maintaining robust functional structures (Jaaron and Backhouse, 2014). The most complex type of functional structure is the integrated design (which could be understood as an integrated solution), in which the service 
functions and physical products and services are intertwined (Persson and Ahlstrom, 2006). Such solutions are difficult to operate because the higher the number of service functions and relations between them, the harder it is to design and optimise (Chen and Liu, 2005; Dahmus et al., 2001; Persson and Ahlstrom, 2006). Service functions that are both valued highly by customers and significantly intertwined with other service functions (Pynnönen et al., 2011). These become the value drivers of the solution; they are called systemic service functions. It is necessary to identify the systemic service functions in a solution's design if one is to optimise the value of the whole solution.

Optimisation according to the literature on product architecture generally refers to product performance (e.g. size, weight) (Ulrich, 1995), but also focuses on value in the service context. Ulrich (1995) defines two types of performance characteristics: local and global. Local performance relates to service functions enabled by a specific component (i.e. with few interrelations) in the functional structure that can be optimised through a modular architecture. Global performance applies to situations in which the service function is enabled by or enables many components and can be optimised only by integral architecture (Ulrich, 1995). Straightforward analysis of the importance of a service function to the customer, for example, would recommend the removal of non-value-creating service functions from the product and service portfolio, but given the systemic interconnections among the service functions, taking off a piece of the system might weaken the value of the whole (Persson and Ahlstrom, 2006; Pynnönen et al., 2011). Because the integration process involves designing, modifying and selecting goods and services that work well with one another (Tuli et al., 2007), the process should be considered in a holistic manner.

\subsection{Provision models for integrated solutions}

Service providers aiming to succeed in the integrated solution business need to understand their 
customer's business goals and processes (Brady et al., 2005). Needs related to service purchasing in business markets could be understood as strategic make-or-buy decisions (Davies et al., 2007). Companies have different strategies for purchasing services, and therefore the service provider should understand what, when and how to integrate (Hallikas et al., 2014). Biggemann et al. (2013) argue that the relational view on integrated solutions (e.g. AarikkaStenroos and Jaakkola, 2012; Tuli et al., 2007) is limited in regard to the problem domain of the customer. Problem domains vary among companies, and different domains require different service models. The provider thus must be able to operate several service provision models, depending on the customer (Windahl and Lakemond, 2010), and solutions must be designed to fit the customer's problem domain.

The transactional model focuses on the creation of transactional relationships for the exchange of physical products and standard services that do not require advanced customer strategies (Helander and Möller, 2007). These business models are built around strictly determined service functions that represent part of the company's offerings alongside other product or service elements (Kapletia and Probert, 2010; Windahl and Lakemond, 2010). The services and products are fairly standardised and modular (Davies et al., 2007; Persson and Ahlstrom, 2006), and the integration takes place on the provider's side, focusing on background operational processes.

Another model derived from the relational view is the operational model, through which the provider defines and operates a solution in collaboration with the customer (Helander and Möller, 2007; Tuli et al., 2007; Windahl and Lakemond, 2010). The challenges in this type of provision involve the management of multitier networks in which the value co-creation potential is framed by common rules, shared responsibilities and the maintenance of fluid relationships between partners (Adel and Wiesner, 2015; Karatzas et al., 2016; Rintala et al., 2016; Weeks and Benade, 2015). The idea is to create technical platforms and joint value 
creation processes through cooperative means without involving the customer's day-to-day routines (Cova and Salle, 2008; Helander and Möller, 2007). Here, integration mainly takes place on the solution level, focusing on optimising performance via the customised service functions and parts of the solution (Persson and Ahlstrom, 2006; Pynnönen et al., 2011).

The performance provider model gives the provider extensive responsibility over customer operations and an important role in long-term value creation for the end customer (Helander and Möller, 2007; Kapletia and Probert, 2010). The provider integrates the solution into the customer's processes, and the relationship resembles a strategic partnership (Windahl and Lakemond, 2010). Integration in this model focuses on both the solution and the customer's business targets, with the solution being tailored to the customer's problems (Helander and Möller, 2007). Despite the high degree of integration, the service functions may be as standard as in the other two models.

\section{Methodology}

A systematic examination of customer value creation was applied to the product and service portfolio of a Finnish infrastructure service provider. The selected service provider is a service integrator in the service supply chain, providing and designing service solutions with its customers and suppliers. The research process employed in the present study had three stages: 1) mapping the case company's product and service portfolio, 2) building a survey instrument and 3) conducting data analysis. The first phase aimed to understand and map the key service functions of the case company's product and service portfolio. It was implemented using workshops with the case company. In phase 2, the key service functions from phase 1 and measurements of customer expectations of value were built as the survey instrument. In phase 3 , the survey was launched to the customers of the case company, and the results were analysed using Social Network Analysis (SNA) and statistical methods. 


\subsection{The case company's product and service portfolio}

The relational service framework proposed by Tuli et al. (2007) was applied to capture all phases of the customer service process (requirements definition, customisation and integration, deployment and post-deployment support), as was the Product-Service System methodology (Ulrich, 1995) to map the service functions from the service provider's product and service portfolio. These were mapped in workshops with the help of a group of experts. The Requirements Definition phase in during the provision of network maintenance services largely involved the strategic planning of networks focused on investments, and was expected to react to signals from outside the industry. Customisation and integration included, for example, activities related to the construction of new electricity and telecom lines and sites and the renewal of existing networks. Deployment included service operations supporting the noninterrupted operation of infrastructure networks. The post-deployment support phase aimed to improve services in the previous sections and provide a channel for feedback and customer contributions.

Specialists from the infrastructure services provider identified the service functions and evaluated the product and service portfolio of the case company. The analysis of the product and service portfolio involved the recognition of service functions related to the existing service concept. These service functions defined the features of the product and service portfolios expected to resolve particular issues raised by customers, thereby providing value. A total of 17 different service functions were identified and selected to be included in the survey instrument (see table 1 in section 4.1 for the complete list of service functions).

\subsection{Survey instrument}

Data collection regarding complex service offerings was conducted using a structured questionnaire survey targeted at the customer base of a Finnish infrastructure service provider. 
The survey was divided into two sections: the service functions of the company and the value of those services. The importance of the service functions to the customers' business was measured using a seven-point Likert scale (1-7). In addition, the SERVQUAL framework (Parasuraman et al., 1988; Ulaga and Chacour, 2001; Yee et al., 2010; Calabrese, 2011) was employed to measure service value. The original model consists of five dimensions: tangibility, reliability, responsiveness, assurance and empathy. In this study, the reliability and assurance dimensions were chosen for analysis; this was in line with Hawkins et al.'s 2015 study, which modified measurement devices to monitor business customers' expectations of value.

\subsection{Sample}

Data was collected by means of a web survey. The respondents were customers of the case company, and their purchases related most frequently to the IT network and energy infrastructure. The respondents all held managerial positions and were chosen for their experience in managing their relationships with the service provider. The survey was sent to the customers via a CRM system. Two weeks after the original posting, a reminder was sent to the same respondent list. The response ratio was 17 percent, representing 149 responses out of 864 sent emails.

\subsection{Data analysis}

Statistical methods and SNA were employed to analyse the survey sample of customer companies. The SNA method was used to describe the structure of the service bundles from the customers' perspective. A regression analysis was applied to connect the expected value of the service solutions to the expected quality attributes and preferred purchasing strategies.

SNA was also used to analyse the functions of the service provider's solutions due to the method's suitability in analysing systems consisting of observation points and the connections between them (Borgatti et al., 2002). The objective of the analysis was to provide an alternative 
system approach to determine connectedness among service functions. It was important to identify the service functions that were central (connected) and powerful (connected with other central service functions); in normal circumstances, these elements form the core of service system integration or the service package in the system. Although elements with low centrality and power can be important, they are not essential in an integrated system. This makes it possible to offer such elements individually or even outsource them to alternative suppliers.

The present study referenced two indicators of network centrality. Degree centrality was chosen as it is the most frequently used measure. In its simplest from, it is based on the number of ties each node in the network possesses (Wasserman and Faust, 1994). For example, a degree score of two can be assigned to a network actor connected with two other nodes. The second indicator, Bonacich's power, functions on the idea that forming connections with neighbours with more connections increases power (Bonacich, 1987; 2007). This indicator accounts for the ties a focal node has with other elements, as well as the centrality of these connected nodes in the network. The present study used Ucinet network analysis software and algorithms to calculate the centrality and power scores for each service element. The observation points were the service functions and the connections forming their statistical correlations (significant at the .01 level [2-tailed]). The network was formulated from the statistical correlations between the service functions' importance in the data.

Regression analysis was used to explain the dependency between service cluster importance and decision-making attributes. In the regression model, the dependent variables were derived from the literature explaining service quality. The independent variables in the model were the summed scales of the service functions' importance. The importance of clusters 1, 2 and 3 was examined in its influence on value expectations regarding reliability and assurance. Each measurement in the model was based on multiple scale items, which were operationalised by unambiguous statements. A Likert scale from 1 to 7 was used to rate the statements in the 
survey, where a number of scale items ranged from 3 to 8 .

\section{Results}

\subsection{Structural network analysis of the service functions}

A correlation-based network cluster analysis was used to examine the relationship structure of the services and drivers of customer value. The starting fit was 1.015 and the overall fit .339 (smaller values indicate a better fit). The R-squared of the analysis was .436. The analysis resulted in the following clusters:

Cluster 1 - Operational Services (service functions F1, F2, F3, F4 and F 16)

Cluster 2 - Transactional Services (service functions F9, F10, F11, F12, F13, F14, F15 and F17)

Cluster 3 - Performance Services (service functions F5, F6 and F7)

Cluster 4 - Outlier (F8)

The nodes shown in figure 2 represent the service functions of the product and service portfolio and how they were integrated in the customers' minds. Node's visual size indicates the importance of the element to the customer (see table 1 for exact values). The presented service network diagram provides a systemic view of both the strength of the ties between the elements and, more precisely, the overall structure of the product and service portfolio. 


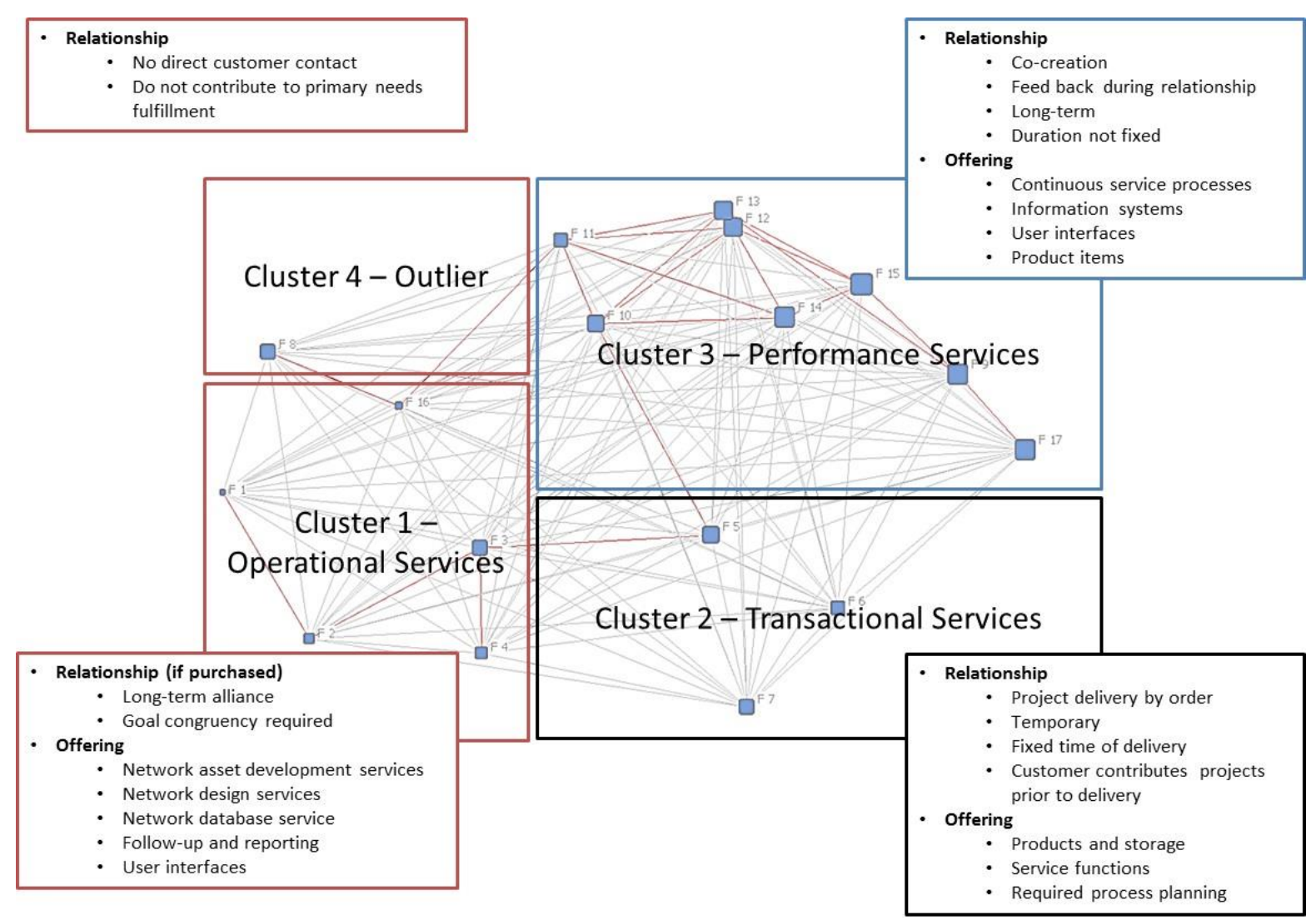

Figure 2. Connections among service functions based on correlations

The purpose of the conducted centrality analysis was to show which service functions exhibited the strongest connections or were the most powerful in relation to other service functions. These service functions were the core elements in the system and generated value in their linkages to other service functions. Table 2 summarises the measurements from the network analysis in terms of degree and power. These measures were compared to the mean importance measure to assess the role of each service function in creating systemic value. The scores were normalised to allow comparison but were not standardised; as such, they are comparable only in a relative sense. The network centralisation (out degree) was 12.436 percent.

Table 1. Measure of network centrality in the investigated service system

Abbr.

SD Importance Bonacich Degree (Mean) Power 


\section{Cluster 1 - Operational Services}

$\begin{array}{lccccc}\text { Helping in network development strategies } & \text { F } 1 & 1,616 & 3.92 & 3.08 & 2.08 \\ \text { Network designing } & \text { F 2 } & 1,899 & 4.69 & 4.70 & 370 \\ \text { Field planning } & \text { F 3 } & 1,615 & 5.27 & 7.61 & 6.61 \\ \text { Aligning processes with customer } & \text { F } 4 & 1.447 & 4.81 & 3.81 & 2.81 \\ \text { Automation } & \text { F 16 } & 1.551 & 4.24 & 4.53 & 3.53\end{array}$

\section{Cluster 2 - Transactional Services}

Work planning

Logistics

Excavation work
F

F 6

F 7

1.644

5.27

3.76

2.76

\section{Cluster 3 - Performance Services}

Quality inspection

Preventive maintenance

Spare part management

Fault situation management

Fault separation

Fault locating (on-site)

Fault repairing

Reporting

\section{Cluster 4 - Outlier}

Connecting networks $\begin{array}{lll}\text { F } 9 & 1.146 \quad 6.07\end{array}$

5.11

F 10

1.289

5.52

7.51

6.51

F 1

1.520

5.15

5.65

4.65

F 12

1.162

5.76

6.30

F 13

1.292

5.79

5.58

4.58

F 14

1.121

6.02

7.05

6.05

F 15

1.156

6.24

7.03

6.03

F 17

.991

5.90

4.24 
The total importance mean of the service functions was 5.33. Consequently, the mean power of all service functions was 5.11, and mean centrality was 4.11 .

The most important service function in Cluster 1 was F3 (5.27); it was also the most powerful (7.61) and central (6.61). In general, this cluster had several low-importance service functions (F1, F2, F4 and F16). The mean importance of Cluster 1 was 4.59, which was lower than the total mean. Its mean power (4.75) and mean centrality (3.75) were also lower than the total mean.

The most important service function in Cluster 2 was F5 (5.53), though its other service functions were also fairly high in importance $(\mathrm{F} 6=5.10$ and $\mathrm{F} 7=5.27)$. The mean importance was 5.30, which was close to the total mean. The most interesting aspect of this cluster was that although the service functions were of significant importance to the customer, they were neither powerful nor central in the service system. The mean power was 3.75 and the mean centrality 2.75 .

The mean importance of Cluster 3 was 5.81, the mean power 6.06 and the mean centrality 5.06, all of which were above the total means of all the service functions. In this cluster, the service functions were all of significant importance to the customers; as such, they were tightly connected to each other. The service functions of highest importance were F15 (6.24), F9 (6.07) and F14 (6.02); F14 and F15 were also high in power (7.05 and 7.03, respectively) and very central (6.05 and 6.03, respectively). F10 and F12 were also interesting in that they had high power (7.51 and 6.30, respectively) and were central (6.51 and 5.30, respectively), but were close to the total mean in importance.

Cluster 4 consisted of only one function (F8), which was of significant importance (5.25) but not powerful (3.43) and not central (2.43). It was distinctive in terms of the rest of the function network in its focus on supporting the processes of the service provider. In general, this function 
concerned the management of the network's status in work processes and did not contribute directly to the creation of customer value. However, network control was critical for the service provider when service processes were underway. The outlier F8 was excluded from further customer value-related analysis.

\subsection{Regression model to explain expected value of service clusters}

The influence of the importance of clusters 1,2 and 3 were tested to measure value expectations (specifically, reliability and assurance) to determine the value creation potential of the needsbased service bundles. The normality distribution of the all-scale variables and the measurement constructs were satisfactory, as indicated by histograms and residual plots. All the composite measurements reached adequate reliability (see table 2) according to Cronbach's alpha, ranging from .69 to .915 where the limit for sufficient level was $\alpha>.6$ (Kline, 2011). The all-analysis was performed using IBM SPSS Statistics 22 to explore the relationships.

Table 2. Reliability of measurement constructs

\begin{tabular}{lcccc} 
Measurement & Items & Mean & SD & Cronbach's $\boldsymbol{\alpha}$ \\
\hline Reliability (REL) & 5 & 6.110 & .817 & .915 \\
Assurance (ASS) & 4 & 5.845 & .867 & .879 \\
Cluster 1 - Operational Services & 5 & 4.614 & 1.285 & .807 \\
Cluster 2 - Transactional Services & & & & .690 \\
Cluster 3 - Performance Services & 3 & 5.288 & 1.186 & .883 \\
\end{tabular}

The influence of the independent variables (i.e. the importance of the clusters) on the dependent variables was tested using separate models, as illustrated in tables 3 and 4 . The enter method was employed in the regression analysis because a definite hypothesis for the relationships had not been set (Tabachnick and Fidell, 2013). The model summary revealed that the all-analysed 
model was statistically significant at $\mathrm{p}<.001$. The prediction power of the models was good for reliability and assurance, where R-squared was over the .20 level. Tables 3 and 4 illustrate the correlation between variables, the standardised coefficient and the statistical significance of the relation. Several observations regarding the influence of the bundles' importance were made from the regression models. The importance of Cluster 3, for example, influenced respondents' expectations regarding reliability $(\beta=.499, \mathrm{p}<.000)$ and assurance $(\beta=.447, \mathrm{p}<.000)$.

Table 3. Correlation between bundle importance and reliability

Dependent: Reliability

\begin{tabular}{lccc}
\hline Measure & $\beta$ & T & Sig. \\
\hline (Constant) & & 7.911 & .000 \\
Cluster 1 - Operational Services & -.118 & -1.304 & .195 \\
Cluster 2 - Transactional Services & .123 & 1.301 & .196 \\
Cluster 3 - Performance Services & .499 & 5.617 & .000 \\
\hline
\end{tabular}

Model Summary: Enter method; $\mathrm{R}=.526 ; \mathrm{R}^{2}=.276 ;$ Sig. $=.000$

Table 4. Correlation between bundle importance and assurance

Dependent: Assurance

\begin{tabular}{lccc}
\hline Measure & $\beta$ & T & Sig. \\
\hline (Constant) & & 6.767 & .000 \\
Cluster 1 - Operational Services & -.063 & -.676 & .500 \\
Cluster 2 - Transactional Services & .108 & 1.113 & .268 \\
Cluster 3 - Performance Services & .447 & 4.889 & .000 \\
\hline
\end{tabular}

Model Summary: Enter method; $\mathrm{R}=.483 ; \mathrm{R}^{2}=.233 ;$ Sig. $=.000$ 


\section{Discussion and conclusions}

\subsection{Discussion of the results}

The identified function clusters' content has been examined to determine the primary purpose, offering and expected relationship between the service provider and the customer. The aim was to recognise features of the observed service subsystems that required particular attention during the service design phase, which might in turn influence service provision. The subsystems were presented as service bundles and named as follows: Cluster 1 - Operational Services, Cluster 2 - Transactional Services, Cluster 3 - Performance Services and Cluster 4 Outlier.

The identified service clusters formed service bundles in which the offerings had varying emphasis on co-creation and orientation in terms of service provision. Cluster 1 included key functions for managing data and connecting service provision networks. It also included planning services to allow access to customer processes, which were advantageous in controlling the service provision networks. The basis for Cluster 1 was also able to be linked to Cluster 4 - Outlier. Cluster 2 was characterised by typical operational services such as product supply activities. This model focused on service integration and solution provision without interaction with the end customer. Cluster 3, which involved maintenance services, was a complex entity because its functions were elements of a continuous process. This cluster also included a central activity, F10, which connected the other functions to a wider service solution to create a local service integration model.

The conducted regression analysis showed that perceived importance of the provision of a solution service bundle had significant impact on the potential value of the service's reliability and assurance. No similar effect could be found among the other service clusters. It was concluded that overall, the analysed function portfolios consisted of different layers on which 
service bundles had local hubs connected to larger, integrated service models. The analysis also revealed that a service network needs global hubs, or service integrators, that are able to coordinate information about the service process throughout the network. This conclusion was further supported by the key functions of each cluster, which were connected to the central function of the network but not necessarily to the other cluster hubs. From the perspective of service modularity, the local networks could be separated from the larger network without affecting their value creation potential, whereas systems lacking a global actor collapsed. Through this, it can be determined that systemic value functions operate on multiple levels, both locally and globally.

\subsection{Theoretical implications}

A complex product and service portfolio providing network maintenance services has been examined to bring practical evidence to the theoretical observation of the systemic nature of customer value (Lusch et al., 2010; Pynnönen et al., 2011). The main contribution of this paper is its systematic analysis of value creation mechanisms in complex service solutions (Englis and Solomon, 1996; Ennen and Richter, 2010; Epp and Price, 2011; Lusch et al., 2010; Normann and Ramirez, 1993; Shocker et al., 2004; Vargo et al., 2008; Dass and Fox, 2011; De Rosa et al., 2013). The contributing SD logic demonstrates that value created collaboratively relates to specific circumstances in which a business relationship impacts customer performance directly, rather than serves as a general feature of service provision. Key relationships have been recognised in the present study as connecting different service operation models (e.g. Windahl and Lakemond, 2010; Helander and Möller, 2007). These connections transfer information from one process to another. It is therefore proposed that the existence of these links either enables or disables the functioning of the service system; inefficient design or a lack of key connections can create bottlenecks in service processes or disable the fluent 
communication between partners. Thus, well-designed connections allow service providers a competitive advantage through the ability to control key network points.

\subsection{Managerial implications}

In the present study, systemic service functions were categorised into two types: local and global (Ulrich, 1995). Local service functions connect with similar service functions to form service bundles, and global service functions connect these bundles together. Analyses of local service functions reveal that to achieve integration on the solution level, a global service function requires the design of interfaces and platforms among and around the local service functions. This is especially important during the designing phase of the solution. The present study's analysis also identified eight service functions (F3, F9, F10, F11, F12, F13, F14, F15), which by definition could be called systemic service functions. These were found to be significant to customers (based on importance) and also strongly connected to other service functions in the solution, making them powerful within the system. All but one of these systemic service functions were related to Cluster 2 , driving the value expectation of customers.

The present results show that although the service functions in company products and service portfolios are uniquely important to the customer, they also form a complex, interconnected value system. Within this value system, connections between certain service functions are stronger and more influential in creating customer value than are others; these may all be found around the domain of customer problems. These findings are in line with the results of previous research (Windahl and Lakemond, 2010). According to these findings, activities related to cocreational relationships and long-term responsibilities to customer process quality value have the most influence on customers' value expectations. Hence, the value generated by relationship attributes is most relevant to continuous supporting services, but it has a lesser role in strategic design or project services. 


\subsection{Limitations and further research}

The limitations of the present study should be taken into consideration when applying its results. First, the data used for the network analysis only reflected customer views on the value creation mechanisms of one company product and service portfolio. The results indicate that the value to the firm lay in its different service functions, and that the system of relationships exhibited these differences as well. This perceived value is subjective, and as such the different service functions deliver value to the provider rather than the customer. This is something that future research should address in studies of systemic customer value, or value provision and capture in general. Second, the statistical correlations observed between service functions as shown in the distributed customer survey were used as the basis of the present analysis. It might be useful in future study to measure these relationships directly. This would not be an easy task, but would serve to explain the phenomenon more completely. Third, the data collected in the present study represents the total customer base of the provider, but it may be that there are different preference profiles within that population. This would mean that the value system would change according to the different profiles. As a final conclusion of this study, the value creation logic of the integrated solutions, in further studies, should be analysed from multiple perspectives and in holistic manner.

\section{References}

Aarikka-Stenroos, L and Jaakkola, E. (2012) "Value co-creation in knowledge intensive business services: A dyadic perspective on the joint problem solving process", Industrial Marketing Management, Vol. 41 No. 1, pp.15-26

Adel, R and Wiesner, S. A. (2015) "Conceptual approach for value driven performance in servitising companies”, International Journal of Services and Operations Management, 
Vol. 21 No. 4, pp.504-531

Alexander, A Walker, H and Naim, M. (2014) "Decision theory in sustainable supply chain management: a literature review" Supply Chain Management: An International Journal, Vol. 19 No. 5/6, pp.504-522

Alonso-Rasgado, T Thompson, G and Elfstrom, B. (2004) "The design of functional (total care) products", Journal of Engineering Design, Vol. 15 No. 6, pp.515-540

Andrews, M L Benedicktus, R L and Brady, M K. (2010) "The effect of incentives on customer evaluations of service bundles", Journal of Business Research, Vol. 63 No. 1, pp.71-76

Bettencourt, L A Ostrom, A L Brown, S W and Roundtree, R I. (2002) "Client co-production in knowledge-intensive business services", California Management Review, Vol. 44 No. 4, pp.100-128

Bonacich, P. (1987) "Power and centrality: A family of measures", American Journal of Sociology, Vol. 92 No. 5, pp.1170-1182

Bonacich, P. (2007) "Some unique properties of eigenvector centrality", Social Networks, Vol. 29 No. 4, pp.555-564

Borgatti, S P Everett, M G and Freeman, L C. (2002) Ucinet for Windows: Software for Social Network Analysis, Analytic technologies.

Bowman, C and Ambrosini, V. (2000) "Value creation versus value capture: Towards a coherent definition of value in strategy", British Journal of Management, Vol. 11 No. 1, pp.1-15

Brady, T Davies, A and Gann, D M. (2005) "Creating value by delivering integrated solutions", International Journal of Project Management, Vol. 23 No. 5, pp.360-365 
Calabrese, A. (2012) "Service productivity and service quality: A necessary trade-off?", International Journal of Production Economics, Vol. 135 No. 2, pp.800-812

Cannon, J. P and Perreault Jr., W D. (1999) “Buyer-Seller Relationships in Business Markets”, Journal of Marketing Research, Vol. 36 No. 4, pp.439-460

Chen, K and Liu, R. (2005) 'Interface strategies in modular product innovation”, Technovation, Vol. 25 No. 7, pp.771-782

Cova, B and Salle, R. (2008) "Marketing solutions in accordance with the S-D logic: Cocreating value with customer network actors", Industrial Marketing Management, Vol. 37 No. 3, pp. 270-277

Dahmus, J B Gonzalez-Zugasti, J P and Otto, K N. (2001) "Modular product architecture", Design Studies, Vol. 22 No. 5, pp.409-424

Dass, M and Fox, G L. (2011) "A holistic network model for supply chain analysis", International Journal of Production Economics, Vol. 131 No. 2, pp.587-594

Davies, A Brady, T and Hobday, M. (2006) "Charting a path toward integrated solutions", MIT Sloan Management Review, Vol. 47 No. 3, pp.39-48

Davies, A Brady, T and Hobday, M. (2007) "Organizing for solutions: Systems seller vs. systems integrator", Industrial Marketing Management, Vol. 36 no. 2, pp.183-193

De Rosa, V Gebhard, M Hartmann, E and Wollenweber, J. (2013) "Robust sustainable bidirectional logistics network design under uncertainty”, International Journal of Production Economics, Vol. 145 No. 1, pp.184-198

Dragoicea, M Falcao, E Cunha, J and Patrascu, M. (2015) “Self-organising socio-technical description in service systems for supporting smart user decisions in public transport", Expert Systems with Applications, Vol. 42 No.17-18, pp.6329-6341 
Englis, B G and Solomon, M R. (1996) "Using consumption constellations to develop integrated communications strategies". Journal of Business Research, Vol. 37 No. 3, pp.183-191

Ennen, E and Richter, A. (2010) "The whole is more than the sum of its parts-- or is it? A review of the empirical literature on complementarities in organizations", Journal of Management, Vol. 36 No.1, pp.207-233

Epp, A M and Price, L L. (2011) 'Designing solutions around customer network identity goals”, Journal of Marketing, Vol. 75 No. 2, pp.36-54

Fliess, S and Kleinaltenkamp, M. (2004) "Blueprinting the service company: Managing service processes efficiently", Journal of Business Research, Vol. 57 No.4, pp.392-404

Flint, D J Woodruff, R B and Gardial, S F. (1997) "Customer value change in industrial marketing relationships: A call for new strategies and research", Industrial Marketing Management, Vol. 26 No. 2, pp.163-175

Geum, Y Lee, S Kang, D and Park, Y. (2011) 'Technology roadmapping for technology-based product-service integration: A case study", Journal of Engineering and Technology Management, Vol. 28 No. 3, pp.128-146

Grönroos, C and Ravald, A. (2011) ”Service as business logic: Implications for value creation and marketing", Journal of Service Management, Vol. 22 No. 1, pp.5-22

Grönroos, C and Voima, P. (2013) "Critical service logic: Making sense of value creation and co-creation", Journal of the Academy of Marketing Science, Vol. 41 No. 2, pp.133-150

Halldórsson, Á Hsuan, J and Kotzab, H. (2015) “Complementary theories to supply chain management revisited - from borrowing theories to theorizing", Supply Chain Management: An International Journal, Vol. 20 No. 6, pp.574-586 
Hallikas, J Immonen, M Pynnönen, M and Mikkonen, K. (2014) ”Service purchasing and value creation: Towards systemic purchases", International Journal of Production Economics, Vol. 147 No. January, pp.53-61

Harmsen, H and Jensen, B. (2004) 'Identifying the determinants of value creation in the market: A competence-based approach", Journal of Business Research, Vol. 57 No. 5, pp.533-547

Hawkins, T G Gravier, M J Berkowitz, D and Muir, W A. (2015) 'Improving services supply management in the defense sector: How the procurement process affects B2B service quality”, Journal of Purchasing and Supply Management, Vol. 21 No. 2, pp.81-94

Helander, A and Möller, K. (2007) ’System supplier's customer strategy”, Industrial Marketing Management, Vol. 36 No. 6, pp.719-730

Hofenk, D Schipper, R Semeijn, J and Gelderman, C. (2011) ”The influence of contractual and relational factors on the effectiveness of third party logistics relationships", Journal of Purchasing and Supply Management, Vol. 17 No. 3, pp.167-175

Howden, C and Pressey, A D. (2008) "Customer value creation in professional service relationships: The case of credence goods", The Service Industries Journal, Vol. 28 No. 6, pp.789-812

Hu, H Kandampully, J and Juwaheer, T D. (2009) "Relationships and impacts of service quality, perceived value, customer satisfaction, and image: An empirical study", The Service Industries Journal, Vol. 29 No. 2, pp.111-125

Jaaron, A and Backhouse, C J. (2014) "Building antifragility in service organisations: Going beyond resilience", International Journal of Services and Operations Management, Vol. 19 No. 4. 
Kapletia, D and Probert, D. (2010) "Migrating from products to solutions: An exploration of system support in the UK defense industry", Industrial Marketing Management, Vol. 39 No. 4, pp.582-592

Karatzas, A Johnson, M and Bastl, M. (2016) "Relationship Determinants of Performance in Service Triads: A Configurational Approach”, Journal of Supply Chain Management, Vol 52 No. 3, pp.28-47

Kline, R B. (2011) Principles and Practice of Structural Equation Modeling, 3 rd edn, The Guilford Press, New York, USA.

Larivière, B Joosten, H Malthouse, E C Marcel, V B Aksoy, P Kunz, W H and Ming-Hui Huang. (2013) "Value fusion”, Journal of Service Management, Vol. 24 No. 3, pp.268293

Levitt, T. (1980) "Marketing success through differentiation-of anything", Harvard Business Review, Vol. 58, pp.83-91

Lin, C Chen, L and Hsu, C. (2011) "An innovative approach for RFID product functions development”, Expert Systems with Applications, Vol. 38 No.12, pp.15523-15533

McDougall, G H G and Levesque, T. (2000) "Customer satisfaction with services: Putting perceived value into the equation", The Journal of Services Marketing, Vol. 14 No.5, pp.392-410

Normann, R and Ramirez, R. (1993) "From value chain to value constellation: Designing interactive strategy" Harvard Business Review, Vol. 71, pp.65-77

Parasuraman, A Berry, L L and Zeithaml, V A (1988) "SERVQUAL: A Multiple-Item Scale For Measuring Consumer Perceptions of Service Quality”, Journal of Retailing, Vol. 64 No. 1, pp.12-40 
Park, Y Geum, Y and Lee, H. (2012) 'Toward integration of products and services: Taxonomy and typology", Journal of Engineering and Technology Management, Vol. 29 No. 4, pp.528-545

Persson, M and Ahlstrom, P. (2006) "Managerial issues in modularising complex products", Technovation, Vol. 26 No. 11, pp.1201-1209.

Pynnönen, M Hallikas, J Ritala, P and Mikkonen, K. (2014) ”Analyzing systemic customer value in scalable business services", The Service Industries Journal, Vol. 34 No. 14, pp.1154-1166

Pynnönen, M Ritala, P and Hallikas, J. (2011) "The new meaning of customer value: A systemic perspective”, The Journal of Business Strategy, Vol. 32 No. 1, pp.51-57

Rintala, A Karppinen, H and Koivuniemi, J. (2016) “Operations management in improving elderly home care”, International Journal of Services and Operations Management, Vol. 24 No. 3, pp.331-362

Roehrich, J K and Caldwell, N D. (2012) 'Delivering integrated solutions in the public sector: The unbundling paradox", Industrial Marketing Management, Vol. 41 No. 6, pp.995-1007

Saccani, N Visintin, F and Rapaccini, M. (2014) "Investigating the linkages between service types and supplier relationships in servitized environments", International Journal of Production Economics, Vol. 149, pp.226-238

Segura, M and Maroto, C. (2017) “A multiple criteria supplier segmentation using outranking and value function methods", Expert Systems with Applications, Vol. 69, pp.87-100

Shankar, V Smith, A K and Rangaswamy, A. (2003) "Customer satisfaction and loyalty in online and offline environments", International Journal of Research in Marketing, Vol. 20 No. 2, pp.153-175 
Shocker, A D Bayus, B L and Kim, N. (2004) "Product complements and substitutes in the real world: The relevance of "other products"”, Journal of Marketing, Vol. 68 No.1, pp.28-40

Tabachnick, B G and Fidell, L S. (2013) Using Multivariate Statistics, Pearson Education, New York, NY.

Thomé, A M T Scavarda, L F Pires, S R I Ceryno, P and Klingebiel, K. (2014) “A multi-tier study on supply chain flexibility in the automotive industry", International Journal of Production Economics, Vol. 158 No. December, pp.91-105

Thomke, S and von Hippel, E. (2002) "Customers as innovators: A new way to create value", Harvard Business Review, Vol. 80, pp.74-81

Tuli, K R Kohli, A K and Bharadwaj, S G. (2007) "Rethinking customer solutions: From product bundles to relational processes”, Journal of Marketing, Vol. 71 No. 3, pp.1-17

Ukko, J and Pekkola, S. (2015) “A framework for a customer approach to performance measurement in a service context", International Journal of Services and Operations Management, Vol. 22 No. 2, pp.210-220.

Ulaga, W and Chacour, S. (2001) "Measuring customer-perceived value in business markets: A prerequisite for marketing strategy development and implementation" Industrial Marketing Management, Vol. 30 No. 6, pp.525-540

Ulrich, K. (1995) "The role of product architecture in the manufacturing firm", Research Policy, Vol. 24 No. 3, pp.419-440

Wang, J Lai, J-Y and Hsiao, L-C. (2015) "Value network analysis for complex service systems: a case study on Taiwan's mobile application services”, Service Business, Vol. 9 No. 3, 381-407

Vargo, S L and Lusch, R F. (2004) “Evolving to a New Dominant Logic for Marketing”, Journal of Marketing, Vol. 68 No. 1, pp. 1-17 
Vargo, S L Maglio, P P and Akaka, M A. (2008) "On value and value co-creation: A service systems and service logic perspective", European Management Journal, Vol. 26 No. 3, pp. $145-152$

Wasserman, S and Faust, K. (1994) Social network analysis: Methods and applications, Cambridge, UK: Cambridge university press.

Weeks, R and Benade, S. (2015) “The development of a generic servitization systems framework", Technology in Society, Vol.43, pp.97-104

Windahl, C and Lakemond, N. (2006) "Developing integrated solutions: The importance of relationships within the network", Industrial Marketing Management, Vol. 35 No. 7, pp.806-818

Windahl, C and Lakemond, N. (2010) "Integrated solutions from a service-centered perspective: Applicability and limitations in the capital goods industry", Industrial Marketing Management, Vol. 39 No. 8, pp.1278-1290

Vivaldini, M and Pires, S R I. (2016) “Logistics service providers coordinating sustainable supply chains: A fast food industry case", International Journal of Services and Operations Management, Vol. 24 No.4.

Yee, R W Y Yeung, A C L and Cheng, T C E. (2010) "An empirical study of employee loyalty, service quality and firm performance in the service industry", International Journal of Production Economics, Vol. 124, pp.109-120

Zhang, M Zhao, X Voss, C and Zhu, G. (2016) "Innovating through services, co-creation and supplier integration: Cases from China", International Journal of Production Economics, Vol. 171, pp.289-300

Zhang, X Chen, R. (2008) 'Examining the mechanism of the value co-creation with customers", International Journal of Production Economics, Vol. 116 No. 2, pp.242-250 
Åhlström, P and Nordin, F. (2006) "Problems of establishing service supply relationships: Evidence from a high-tech manufacturing company", Journal of Purchasing and Supply Management, Vol. 12 No. 2, pp.75-89 